\title{
Study on improving silicone losses in the process of mixing components of soldering machines
}

\author{
Mihai Victor Zerbes ${ }^{1, *}$, and Liliana Georgeta Popescu ${ }^{1}$ \\ ${ }^{1}$ Lucian Blaga University of Sibiu, Industrial Engineering and Management Department, 550025, Victoriei Bld. no.10, Sibiu, Romania
}

\begin{abstract}
The paper presents a summary of the steps of the 6 Sigma methodology applied in the gluing section within an automotive company form Sibiu, Romania. We describe the synthesis of each step of the DMAIC model, a well-known model in the application of the 6 Sigma methodology. In the last chapter, we outline some general conclusions regarding the use of the 6 Sigma methodology presenting the benefits both within the automotive organization from Sibiu and its general use by industrial organizations.
\end{abstract}

\section{Introduction}

This study is conducted at an automotive company form Sibiu in Gluing Division. The approach is based on production processes. The purpose of this case study is to present a problem-solving project based on the 6 sigma methodology. This is a real problem faced by the organization, linked to the involvement of employees in research-innovation projects.

This company is part of a bigger multinational corporation. Its global products include: steering wheels, airbag systems, airbag fabrics, pyrotechnic capsules, safety belts, child safety chairs, electronic components and interior car sensors. The subsidiary of Sibiu has, as its main field, the manufacture of airbags for motor vehicles.

The airbag consists of the following parts: textile, sensor, electronic control unit and pyrotechnic capsule. Textile parts of the airbag are different depending on the type of airbag and model. Thus, it is distinguished: the driver's/steering wheel, passenger, knee, side and curtain airbags (Fig. 1), which in turn differ according to the model of the vehicle for which are intended.

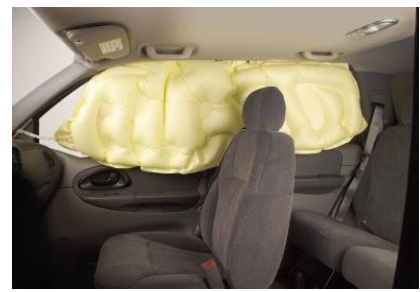

Fig. 1. Head side airbag, curtain type [1]

The driver's airbag is located inside the steering wheel. Head side airbag is located in the roof of the car. They can have different tubular shapes, or mounted in the door depending on application needs.

During the production of these products there were identified delays due to the silicon losses occurred during the mixing of components in the Gluing section.

\section{Methodology}

The Six Sigma methodology - a methodology initiated in the 1980's at Motorola as a challenge to achieve a reduction in the number of defective products - was used to identify the causes and to solve the problems [2]. In order to achieve this effect, a thorough analysis of the causes and possibilities of correction was needed. Sigma is a term taken from statistics, used to measure the variation of a process to specifications or to another reference such as consumer requirements. The higher sigma level, the better the customer's requirements. Thus, it can be said: the probability of events being in the range [3]:

- $\quad[-\sigma ; \sigma]$ is of $68 \%$;

- $\quad[-2 \sigma ; 2 \sigma]$ is of $95 \%$;

- $\quad[-3 \sigma ; 3 \sigma]$ is of $99,73 \%$;

- $\quad[-6 \sigma ; 6 \sigma]$ is of $99,9997 \%$

so, the probability that the event is not in the range $[-6 \sigma$; $6 \sigma]$ is of $3,4 \times 10^{-6} \%$ :

A six sigma improvement process comprises a series of steps, grouped by type of activity as follows [4]:

Step 1. Definition - the deficiencies to be addressed will be clearly specified and the estimated improvement defined in measurable terms. It establishes a team for the project and allocates the resources and time it takes for the project to succeed.

Step 2. Measurement / Analysis - At this stage the team discovers the true causes of the deficiency.

Step 3. Improve - Establish improvements for identified causes.

Step 4. Control - the improvement team develops and implements control elements.

Step 5. Multiply the results - once the improvement team has positive results, there are two more responsibilities: to support other employees in organization with similar problems to apply what the team has learned from the improvement project, and to

* Corresponding author: mihai.zerbes@ulbsibiu.ro 
nominate other projects for solving in order to correct a deficiency.

\section{Case study - applying the sigma methodology in the case of silicon losses occurring in the components mixing process}

This case study was conducted in the Gluing section, starting from the production processes [5].

\subsection{Defining}

The project is applied in the gluing section for soldering machines. A 5W1H questionnaire (Table 1) applied to 25 people in the Gluing section was used as a tool for formulating the problem.

Table 1. The 5W1H questionnaire

\begin{tabular}{|c|l|l|}
\hline 5W1H & \multicolumn{1}{|c|}{ Questions } & \multicolumn{1}{c|}{ Answers } \\
\hline Which & $\begin{array}{l}\text { Which is the } \\
\text { opportunity / } \\
\text { insatisfaction? }\end{array}$ & $\begin{array}{l}\text { The difference between } \\
\text { component A and B of } \\
40491 € / 8 \text { months }\end{array}$ \\
\hline How & $\begin{array}{l}\text { How do we know } \\
\text { about this } \\
\text { possibility? }\end{array}$ & $\begin{array}{l}\text { Following inventory made } \\
\text { periodically }\end{array}$ \\
\hline When & $\begin{array}{l}\text { When does this } \\
\text { happen? }\end{array}$ & $\begin{array}{l}\text { When mixing the silicone } \\
\text { components A and B }\end{array}$ \\
\hline Where & Where is it going? & On soldering machines (M3) \\
\hline
\end{tabular}

\begin{tabular}{|l|l|l|}
\hline 5W1H & \multicolumn{1}{|c|}{ Questions } & \multicolumn{1}{c|}{ Answers } \\
\hline Who & Who is involved? & $\begin{array}{l}\text { Operators / exchange, } \\
\text { engineers }\end{array}$ \\
\hline Why & $\begin{array}{l}\text { Why is this aspect } \\
\text { of the business a } \\
\text { problem? }\end{array}$ & $\begin{array}{l}\text { This affects us financially by } \\
\text { throwing out the silicone } \\
\text { component that expires with } \\
\text { no pair }\end{array}$ \\
\hline
\end{tabular}

Following the analysis of the results of the $5 \mathrm{~W} 1 \mathrm{H}$ questionnaires, the problem to be solved was formulated as follows: "Silicone losses when mixing the components".The project team consisted of project manager (Quality Engineer), Quality Team Chief, Prototype Engineer, Process Enhancement Engineer, Logistics Team Coordinator, Maintenance Engineer, Chief Laboratory Team.

\subsection{Measuring range}

The structure of the measurement stage consists of 7 steps for which specific actions have been taken. The key milestones for the masonry phase are: customer voice, setting measurement aspects, validating measurement systems, detecting influence factors, measuring planning, visualizing graphical measurements and performance of the process.

\subsection{Customer voice}

In the measurement phase, the expectations, requirements and specifications of the internal clients are summarized in Table 2.

Table 2. Customer voice

\begin{tabular}{|c|c|c|c|c|c|}
\hline Customer & Expectations & Requirements & C T Q & Specifications & Weight \\
\hline \multirow{2}{*}{ Gluing } & $\begin{array}{l}\text { Observance of } \\
\text { ration of } 1: 1\end{array}$ & $\begin{array}{c}\text { Decrease in proportion between } \\
\text { component } \mathrm{A} \text { and } \mathrm{B} \text { from } 2.5 \% \text { to } 1.6 \%\end{array}$ & $\begin{array}{l}\text { Big difference of } 1: 5 \text { between } \\
\text { component } \mathrm{A} \text { and } \mathrm{B} \text { (Race) }\end{array}$ & $\begin{array}{l}\text { according to the } \\
1: 1 \text { ratio }\end{array}$ & $25 \%$ \\
\hline & $\begin{array}{l}\text { Technological } \\
\text { losses }\end{array}$ & Not to exceed more than $10 \%$ & $\begin{array}{l}\text { Incorporation into normal } \\
\text { consumption }\end{array}$ & maximum $10 \%$ & $55 \%$ \\
\hline Laboratory & $\begin{array}{l}\text { Fitted parts } \\
\text { according to the } \\
\text { standard }\end{array}$ & $\begin{array}{l}\text { The proportion of component } \mathrm{A} \text { and } \mathrm{B} \\
\text { is } 1: 1\end{array}$ & $\begin{array}{c}\text { Resistance to silicon at break> } \\
175 \mathrm{~N}\end{array}$ & $>175 \mathrm{~N}$ & $10 \%$ \\
\hline Logistics & $\begin{array}{l}\text { Reduce silicone } \\
\text { scrapping due to } \\
\text { expiration }\end{array}$ & $\begin{array}{l}\text { Proportional use of components A and } \\
\text { B }\end{array}$ & $\begin{array}{c}\text { Compliance with the date of } \\
\text { validity of components A and B }\end{array}$ & $\begin{array}{l}\text { Using FIFO of } \\
\text { silicone barrels }\end{array}$ & $10 \%$ \\
\hline
\end{tabular}

\subsubsection{Establishing aspects of measurement}

In order to better understand the change process, the measurement factors have been prioritized (Table 3 )

Table 3. Prioritization of measurement factors $Y$

\begin{tabular}{|l|l|c|}
\hline No. & Measurement factor Y & Weight \\
\hline 1 & Ration & $25 \%$ \\
\hline 2 & Resistance to tearing $>175 \mathrm{~N}$ & $10 \%$ \\
\hline 3 & Costs & $10 \%$ \\
\hline
\end{tabular}

Validation of measuring systems was done with a specialized "Measurement System Analysis" system shown in Fig. 2.

\subsubsection{Detection of influence factors}

In order to detect the possible causes of the problem, the Ishikawa diagram was used. The main cause was "The Stock Difference Between Components A and B Generated by Ratio Variation".

\subsubsection{Planning the measurements}


The mixing process is influenced by the following parameters: D1-speed on the route; D2-starting speed; D3-speed of absorption.

Leakage velocity may be influenced by viscosity (different viscosity between the two components). The influence of viscosity on the mixing process can be expressed by the difference between rations due to the slower or faster leakage of components A and B through the pipe. The monitoring of the mixing process is presented in Tables 4 and 5.

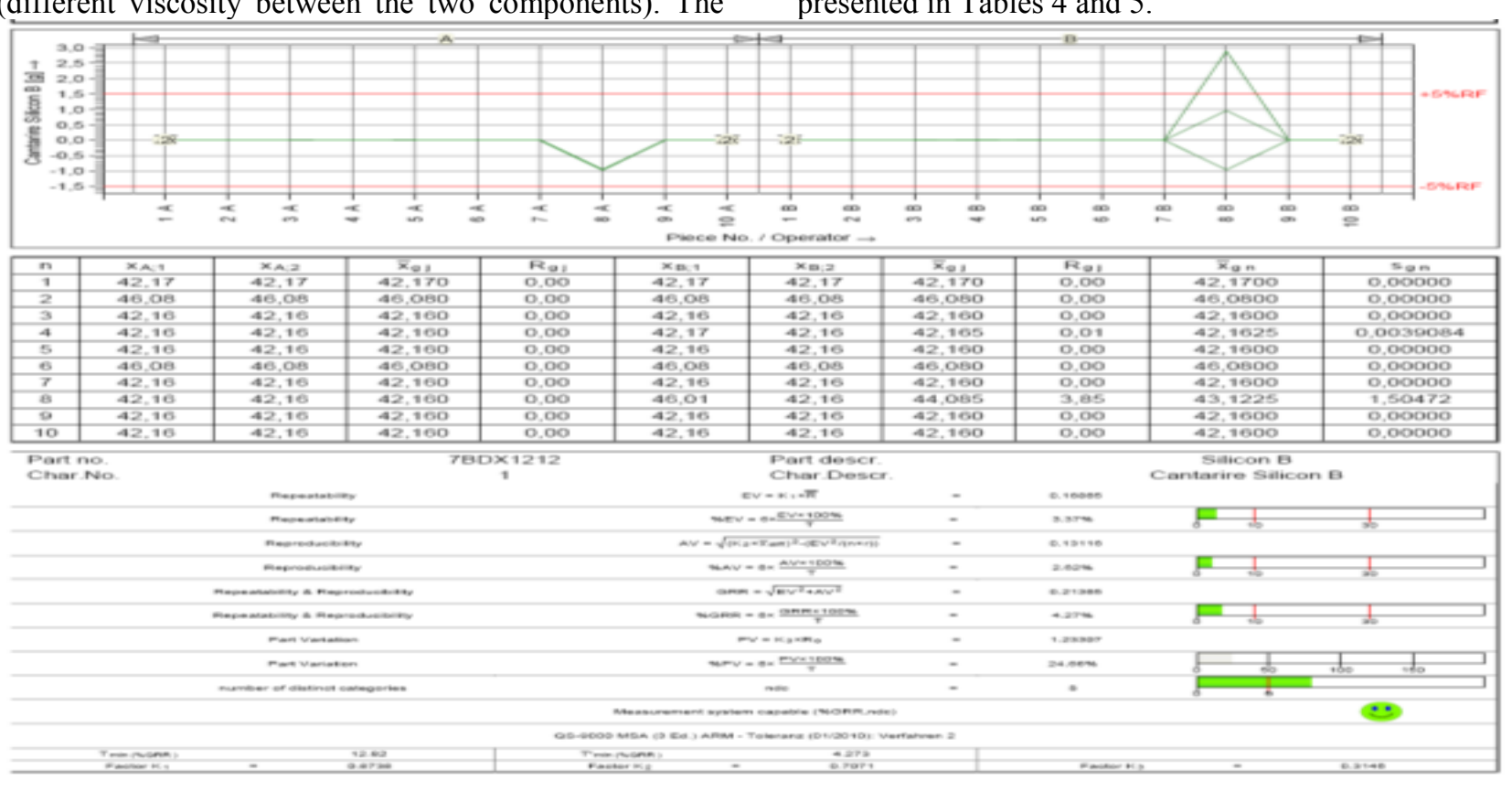

Fig. 2. Analysis of measurement systems using electronic balance

\subsubsection{Planning the measurements}

The mixing process is influenced by the following parameters: D1-speed on the route; D2-starting speed; D3-speed of absorption.

Leakage velocity may be influenced by viscosity (different viscosity between the two components). The influence of viscosity on the mixing process can be expressed by the difference between rations due to the slower or faster leakage of components A and B through the pipe. The monitoring of the mixing process is presented in Tables 4 and 5.

Table 4. Monitoring of the mixing process during January 24February 032017 on first exchange.

\begin{tabular}{|c|c|c|c|c|}
\hline Data & $\begin{array}{c}\text { Silicone } \\
\text { A } \\
\text { Viscosity }\end{array}$ & $\begin{array}{c}\text { Silicone A } \\
\text { Temperature }\end{array}$ & $\begin{array}{c}\text { Silicone } \\
\text { B } \\
\text { Viscosity }\end{array}$ & $\begin{array}{c}\text { Silicone B } \\
\text { Temperature }\end{array}$ \\
\hline 24.01 & 341,4 & 29,3 & 371,5 & 28,9 \\
\hline 25.01 & 332,2 & 28,7 & 362,3 & 28,2 \\
\hline 26.01 & 326,6 & 26,7 & 386,2 & 26,6 \\
\hline 27.01 & 360 & 27,3 & 341,5 & 28,3 \\
\hline 28.01 & 300,9 & 28 & 322,8 & 28,3 \\
\hline 30.01 & 372 & 23 & 338,1 & 23,4 \\
\hline 31.01 & 378,2 & 25,6 & 333,3 & 25,7 \\
\hline 01.02 & 378,3 & 25,9 & 318,3 & 25,8 \\
\hline 02.02 & 321,9 & 26,2 & 274,8 & 26 \\
\hline 03.02 & 392 & 25,3 & 356,6 & 25,2 \\
\hline
\end{tabular}

Table 5. Monitoring of the mixing process during January $24-$ February 062017 on second exchange

\begin{tabular}{|c|c|c|c|c|}
\hline Data & $\begin{array}{c}\text { Silicone A } \\
\text { Viscosity }\end{array}$ & $\begin{array}{c}\text { Silicone A } \\
\text { Temperature }\end{array}$ & $\begin{array}{c}\text { Silicone B } \\
\text { Viscosity }\end{array}$ & $\begin{array}{c}\text { Silicone B } \\
\text { Temperature }\end{array}$ \\
\hline 24.01 & 350 & 28,4 & 356,3 & 29,4 \\
\hline 25.01 & 352,2 & 28,3 & 332,2 & 28,7 \\
\hline 26.01 & 336,6 & 28,7 & 348,9 & 29,1 \\
\hline 27.01 & 355,3 & 28,7 & 316,5 & 29,2 \\
\hline 28.01 & 355,4 & 27,6 & 279 & 28,1 \\
\hline 30.01 & 315 & 27,7 & 361 & 27,4 \\
\hline 31.01 & 315,2 & 27,8 & 351,3 & 26,8 \\
\hline 01.02 & 320 & 28 & 299,1 & 27,7 \\
\hline 02.02 & 201,2 & 27,8 & 351,3 & 27 \\
\hline 03.02 & 387 & 26,1 & 297,7 & 25,4 \\
\hline 06.02 & 311,6 & 27,3 & 291 & 26,7 \\
\hline
\end{tabular}

A range of values for the three machine parameters for silicone type A and type B has been established and their influence on the ratio by two methods has been monitored. Ratio by method 1 - the classical method used in the line is allowed to flow 40 seconds silicone type $\mathrm{A}$ and then type B, after which weigh.

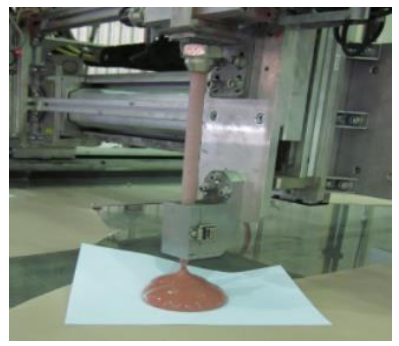

Fig.3. The weighing process of the type A component [1] 
Ratio by Method 2 consists of depositing A and B type silicon on the panel, according to a route corresponding to each model (BMW F10).

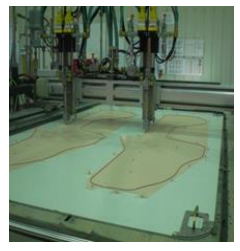

Fig. 4. Silicone component type A deposition process [1]
The values obtained by changing the parameters on the ratio through the two test methods for components $\mathrm{A}$ and $\mathrm{B}$ are presented in Table 6. Following the modification of the parameters, the values are obtained which are highlighted in the graphs of Fig. 5 and Fig. 6, taking the and base ratio in percent (difference between components $\mathrm{A}$ and $\mathrm{B}$ in grams).

Table 6. Data collection sheet

\begin{tabular}{|c|c|c|c|c|c|c|c|c|c|c|c|c|c|c|c|c|c|c|c|c|c|c|c|c|c|}
\hline \multicolumn{3}{|c|}{ rosu $A 2$} & \multicolumn{3}{|c|}{ alb 82} & \multirow[t]{2}{*}{ A } & \multirow[t]{2}{*}{ B } & \multirow{2}{*}{ M3 TEST 1} & \multirow[t]{2}{*}{ A } & \multirow[t]{2}{*}{ B } & \multirow{2}{*}{ M3 TEST 2} & \multirow[t]{2}{*}{ A } & \multirow[t]{2}{*}{ B } & \multirow{2}{*}{ M3 TEST 3} & \multirow[t]{2}{*}{ Medie } & \multirow[t]{2}{*}{ A } & \multirow[t]{2}{*}{ B } & \multirow{2}{*}{ M1 TEST 1} & \multirow[t]{2}{*}{ A } & \multirow[t]{2}{*}{ B } & \multirow{2}{*}{ MITEST 2} & \multirow[t]{2}{*}{ A } & \multirow[t]{2}{*}{$B$} & \multirow[b]{2}{*}{ M1 TEST 3} & \multirow[t]{2}{*}{ Medie } \\
\hline 021 & 022 & 023 & D31 & D32 & 033 & & & & & & & & & & & & & & & & & & & & \\
\hline 800 & 800 & \begin{tabular}{|l|l|}
-450 \\
\end{tabular} & 842 & 698 & -450 & \begin{tabular}{|l|}
44.3 \\
\end{tabular} & 49.9 & -5.98 & 46.6 & 49.9 & -3.44 & 46.5 & 49.23 & -2.83 & -4.082 & 58.2 & 63.6 & -4.44 & 58.2 & $\begin{array}{ll}62.5 \\
\end{array}$ & -3.56 & 58.3 & \begin{tabular}{l|l}
62.6 \\
\end{tabular} & -3.57 & -3.8584 \\
\hline 850 & 800 & -450 & 842 & 698 & -450 & 48.5 & 53 & -4.45 & \begin{tabular}{|l|}
48.78 \\
\end{tabular} & 53.3 & -4.38 & 48.8 & 53.03 & -4.19 & -4.34218 & 60.9 & 66.2 & -4.24 & 66.2 & 61 & 4.08 & 61.1 & 66.1 & -3.98 & \begin{tabular}{|l|}
-1.37995 \\
\end{tabular} \\
\hline 900 & 800 & \begin{tabular}{|l}
-450 \\
\end{tabular} & 842 & 698 & -450 & \begin{tabular}{|l|}
49.6 \\
\end{tabular} & 50.2 & -0.59 & \begin{tabular}{|l|}
49.9 \\
\end{tabular} & 50.2 & -0.30 & 499.9 & 50.38 & -0.44 & -0.44302 & 62.7 & 62.8 & -0.07 & 66.9 & 62.9 & 3.01 & 62.7 & 63 & -0.29 & 0.884811 \\
\hline 847 & 750 & \begin{tabular}{|l|l|}
-450 \\
\end{tabular} & 842 & 698 & -450 & \begin{tabular}{|l|}
47.9 \\
\end{tabular} & 51.4 & -3.53 & 48.29 & 52 & -3.69 & 48.3 & 51.84 & -3.49 & -3.56982 & 59.9 & 64.1 & -3.45 & 60 & 64.3 & -3.53 & 60.2 & 64.3 & -3.31 & \begin{tabular}{|l|}
-3.43187 \\
\end{tabular} \\
\hline 847 & 800 & \begin{tabular}{|l|l|}
-450 \\
\end{tabular} & 842 & 698 & -450 & & & & & & & & & & & & & & & & & & & & \\
\hline 847 & 850 & \begin{tabular}{|l|}
-450 \\
\end{tabular} & 842 & 698 & -450 & 48 & 51.1 & -3.10 & \begin{tabular}{|l|l|}
47.97 \\
\end{tabular} & 51.4 & -3.47 & 48.2 & 51.74 & -3.51 & -3.35972 & 59.6 & 65.1 & -4.42 & 59.8 & 65.2 & -4.31 & 59.9 & 61.7 & -1.48 & -3.40541 \\
\hline 847 & 800 & -400 & 842 & 698 & -450 & 48 & 50.5 & -2.51 & 48.48 & 51 & -2.56 & 48.6 & 50.97 & -2.37 & -2.47979 & 59.6 & 65.1 & -4.38 & 59.8 & 65.1 & -4.27 & 60 & 64.9 & -4.00 & \begin{tabular}{|l|}
-4.21278 \\
\end{tabular} \\
\hline 847 & 800 & -450 & 842 & 698 & -450 & & & & & & & & & & & & & & & & & & & & \\
\hline 847 & 800 & .500 & 842 & 698 & -450 & 49 & 51.9 & -2.87 & 49.69 & 52.2 & -2.42 & 49.7 & $\begin{array}{lll}49.74 \\
\end{array}$ & 0.00 & -1.7604 & 61.9 & 65.8 & -3.06 & 62.3 & 64.4 & -1.67 & 62.4 & 65.7 & -2.54 & \begin{tabular}{|l|}
-2.42458 \\
\end{tabular} \\
\hline 847 & 800 & -450 & 800 & 698 & -450 & \begin{tabular}{|l|}
49.8 \\
\end{tabular} & 50.2 & -0.38 & \begin{tabular}{|l|}
50.19 \\
\end{tabular} & 50.7 & -0.50 & 50 & 50.95 & -0.90 & -0.59216 & 62.5 & 64.8 & -1.80 & 62.6 & 65 & -1.92 & 62.7 & 65.2 & -1.96 & \begin{tabular}{|l|l|} 
\\
\end{tabular} \\
\hline 847 & 800 & -450 & 850 & 698 & -450 & & & & & & & & & & & & & & & & & & & & \\
\hline 847 & 800 & -450 & 900 & 698 & -450 & 50.1 & 55.6 & -5.19 & \begin{tabular}{|l|l|}
49.98 \\
\end{tabular} & 55.8 & -5.54 & \begin{tabular}{|l|l|}
50.2 \\
\end{tabular} & 55.93 & -5.37 & -5.36615 & 62.6 & \begin{tabular}{|l|l|}
69.1 \\
\end{tabular} & -4.98 & 62.5 & 69.5 & -5.29 & 62.6 & 69.7 & -5.36 & \begin{tabular}{|l}
-5.20889 \\
\end{tabular} \\
\hline 847 & 800 & -450 & 842 & 650 & -450 & 50.2 & 53.6 & -3.25 & 50.29 & 53.5 & -3.13 & 50.1 & 53.68 & -3.42 & -3.26601 & 62.5 & 67.1 & -3.53 & 62.6 & 67.2 & -3.51 & 62.7 & 67.3 & -3.49 & \begin{tabular}{|l|}
-3.50834 \\
\end{tabular} \\
\hline 847 & 800 & -450 & 842 & 700 & -450 & & & & & & & & & & & & & & & & & & & & \\
\hline 847 & 800 & -450 & 842 & 750 & -450 & \begin{tabular}{|l|}
46.5 \\
\end{tabular} & 49.4 & -3.01 & \begin{tabular}{|l|l|}
48.88 \\
\end{tabular} & 50.9 & -1.99 & 48.9 & 50.98 & -2.07 & -2.35648 & 59.4 & \begin{tabular}{|l|l|}
64.3 \\
\end{tabular} & \begin{tabular}{|l|}
-3.93 \\
\end{tabular} & 60.2 & 64.5 & $\begin{array}{l}-3.50 \\
\end{array}$ & $\begin{array}{l}60.3 \\
\end{array}$ & \begin{tabular}{|c|}
63.9 \\
\end{tabular} & -2.94 & \begin{tabular}{|l|}
-3.45482 \\
\end{tabular} \\
\hline 847 & 800 & \begin{tabular}{|l|l|}
-450 \\
\end{tabular} & 842 & 698 & -400 & \begin{tabular}{|l|l|}
48.4 \\
\end{tabular} & 49.9 & \begin{tabular}{|c|}
-1.57 \\
\end{tabular} & \begin{tabular}{|l|l|}
48.79 \\
\end{tabular} & 50.4 & -1.62 & \begin{tabular}{|l|l|}
48.8 \\
\end{tabular} & 50.32 & $\begin{array}{l}-1.55 \\
\end{array}$ & -1.58115 & 60.4 & 61.4 & \begin{tabular}{|c|c|} 
\\
\end{tabular} & 60.4 & $\begin{array}{l}62.5 \\
\end{array}$ & $\begin{array}{l}-1.74 \\
\end{array}$ & 58.5 & $\begin{array}{l}62.7 \\
\end{array}$ & -3.50 & -2.02883 \\
\hline 847 & 800 & \begin{tabular}{|l|}
-450 \\
\end{tabular} & 842 & 698 & -450 & & & & & & & & & & & & & & & & & & & & \\
\hline 847 & 800 & \begin{tabular}{|l|l|}
-450 \\
\end{tabular} & 842 & 698 & .500 & \begin{tabular}{|l|}
47.9 \\
\end{tabular} & \begin{tabular}{|l|l|}
49.8 \\
\end{tabular} & \begin{tabular}{|c|}
-1.90 \\
\end{tabular} & \begin{tabular}{|l|l|}
47.97 \\
\end{tabular} & 50 & -2.06 & 48 & 46.63 & 1.45 & -0.8395 & 59.2 & 61.6 & \begin{tabular}{|l|} 
\\
\end{tabular} & 59.2 & \begin{tabular}{|l|l|}
61.7 \\
\end{tabular} & \begin{tabular}{|c|} 
\\
\end{tabular} & $\begin{array}{l}59.5 \\
\end{array}$ & \begin{tabular}{|l|}
61.7 \\
\end{tabular} & \begin{tabular}{|c|}
-1.89 \\
\end{tabular} & -1.98095 \\
\hline
\end{tabular}

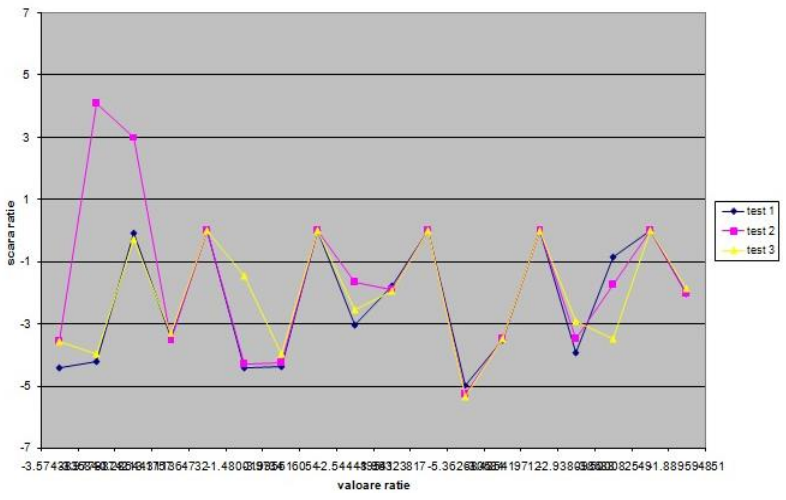

Fig. 5. Ratio by method 1 following tests $1,2,3$

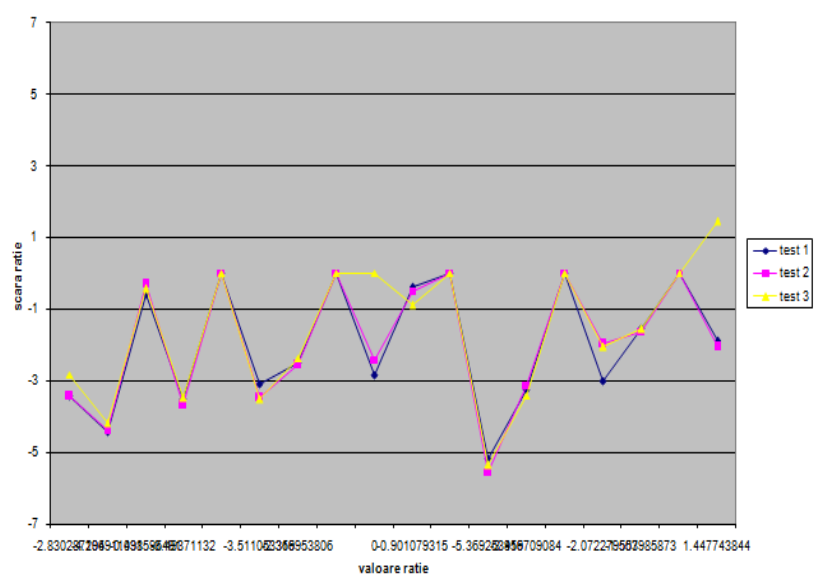

Fig. 6. Ratio by method 2 following tests $1,2,3$

\subsection{Analyze}

\subsubsection{Find and prioritize the main causes that impact on performance}

For identification of the root cause the following questionnaire was made (Table 8).

Due to the fact that the ratio is higher than the maximum admissible $5 \%$, the consumption of the two components $\mathrm{A}$ and $\mathrm{B}$ is different.

Table 9 shows the difference in $\mathrm{Kg}$ between January and May.

Following the calculations, the difference between consumption (formula 1) and ration (formula 2) was double.

$$
\begin{gathered}
\text { Consumption }=A /(B-1) \\
\text { Ration }=[(A-B) /(A+B)] * 100
\end{gathered}
$$

The different perception of consumption and ration has made for values of rationality considered good (difference to $2.5 \%$ versus maximum specification of $5 \%$ ), in fact to be too high for the proposed objective, because the calculation formulas for consumption and ration give totally different results. Consumption $1 \%$ different from ration $1 \%$. 
Table 8. The 5 WHY questionnaire

\begin{tabular}{|l|l|l|l|l|l|l|}
\hline No. & \multicolumn{1}{|c|}{ Causes } & \multicolumn{1}{c|}{ Why } & \multicolumn{1}{c|}{ Why } & \multicolumn{1}{c|}{ Why } & \multicolumn{1}{c|}{ Why } \\
\hline 1 & $\begin{array}{l}\text { The stock gap } \\
\text { generated by } \\
\text { misinterpretation } \\
\text { between ration and } \\
\text { consumption }\end{array}$ & $\begin{array}{l}\text { Because the stock gap is } \\
\text { calculated according to } \\
\text { the consumer formula } \\
\text { logistics department, and } \\
\text { in the production line the } \\
\text { difference between } \\
\text { components A and B is } \\
\text { calculated using the } \\
\text { different ration formulas. }\end{array}$ & $\begin{array}{l}\text { The calculation, } \\
\text { accounting and } \\
\text { technical formulas } \\
\text { have not been } \\
\text { correlated. }\end{array}$ & $\begin{array}{l}\text { The technical objective } \\
\text { did not take into account } \\
\text { the inventory, but only } \\
\text { the technical } \\
\text { performance of the } \\
\text { product (the strength of } \\
\text { the silicone cord at } \\
\text { break) }\end{array}$ & $\begin{array}{l}\text { The specified } \\
\text { technical range of } \\
\text { ration allowed } \\
\text { increased } \\
\text { consumption without } \\
\text { taking into account } \\
\text { the implications in } \\
\text { the inventory of } \\
\text { components. }\end{array}$ \\
\hline $\begin{array}{l}\text { the allowed ration is up } \\
\text { to 5\% and the ration } \\
\text { optimization has not } \\
\text { been taken into } \\
\text { obain the technical } \\
\text { parameter (breaking } \\
\text { strength) with a more } \\
\text { balanced consumption. }\end{array}$ \\
\hline 3
\end{tabular}

Table 9. Comparative analysis between the two methods

\begin{tabular}{|l|c|c|c|c|}
\hline \multirow{2}{*}{ Month } & \multicolumn{2}{|c|}{ Machine M3P5 } & \multicolumn{2}{c|}{ Machine M3P5 } \\
\cline { 2 - 5 } & A & B & A & B \\
\hline January & 1448,62 & 1477,16 & 1365,97 & 1410,19 \\
\hline February & 1685,53 & 1657,45 & 1630,63 & 1653,23 \\
\hline March & 1381,38 & 1395,26 & 1311,45 & 1321,44 \\
\hline Aprilie & 1270,46 & 1341,6 & 1259,91 & 1315,31 \\
\hline May & 1264,77 & 1321,84 & 1135,74 & 1198,62 \\
\hline Amount & 7050,76 & 7193,31 & 6703,7 & 6898,79 \\
\hline Consumption & \multicolumn{2}{|c|}{$-1,98$} & \multicolumn{2}{c|}{$-2,83$} \\
\hline Ration & \multicolumn{2}{|c|}{$-1,00$} & \multicolumn{2}{c|}{$-1,43$} \\
\hline
\end{tabular}

\subsubsection{Updating project benefits (based on root cause analysis)}

Following the implementation of the optimal parameters on head 5 , the average ration of $0.28 \%$ was obtained, comparing it with the average of the ration in
April $(2.71 \%)$ there was a decrease of the ration by $10.33 \%$, but comparing with the change in machine parameters is a drop of only $6 \%$. By making an analogy for head 6 (which rate in April was 2.17\%) to bring it to a value of $0.22 \%$, (which means a $8.11 \%$ reduction in the rate) should be we modify machine parameters not by $8 \%$, but by $4 \%$.

\subsection{Improving}

\subsubsection{Generating ideas for solutions}

The evaluation criteria for the alternatives previously developed are: total cost, impact on the problem, cost $/$ benefit relationship, resilience / impact on change, implementation time, uncertainty about efficacy.

The main solutions that were found following a brainstorming session (Table 10):

Table 10. Developing alternatives for improvement

\begin{tabular}{|l|l|l|}
\hline \multicolumn{1}{|c|}{ Cause } & \multicolumn{1}{|c|}{ Alternative 1 } & \multicolumn{1}{c|}{ Alternative 2 } \\
\hline $\begin{array}{l}\text { a. } \text { Not respecting the } \\
\text { ration }\end{array}$ & $\begin{array}{l}\text { a.1. Reducing the specified range from a } \\
\text { maximum of 5\% to 2.5\% }\end{array}$ & $\begin{array}{l}\text { a.2. Adjustment of rations in process to 2.5\% and } \\
\text { their validation by silicon breaking strength }>175 \mathrm{~N}\end{array}$ \\
\hline $\begin{array}{l}\text { b. } \text { Deregulation of } \\
\text { parameters on } \\
\text { machine 3 head 6 }\end{array}$ & $\begin{array}{l}\text { b.1. Adjusting the parameters of the machine 3 } \\
\text { the head 6 according to the optimal parameters } \\
\text { set for the head 5 }\end{array}$ & $\begin{array}{l}\text { b.2. Following the ratios obtained from the } \\
\text { alignments of the head 6 with optimal parameters } \\
\text { from head 5 }\end{array}$ \\
\hline c. Lossless monitoring & $\begin{array}{l}\text { c.1. Drafting Loss Sheets and communicating } \\
\text { these losses to the logistics department }\end{array}$ & \\
\hline
\end{tabular}

\subsubsection{Prioritize solutions}

In order to evaluate the improvement alternatives against these criteria, the team used as a quality tool the alternative selection matrix (Table 11) where it used the following notations: 3 - Very favorable impact, 2 Favorable medium impact, 1 - Poor impact .

Table 11. Matrix for selecting the alternatives

\begin{tabular}{|c|c|c|c|c|c|c|c|c|}
\hline \multirow{2}{*}{ Cause } & \multirow{2}{*}{ The alternative of improvement } & \multicolumn{6}{|c|}{ Selection criteria } & \multirow{2}{*}{ Total } \\
\hline & & $\mathbf{a}$ & b & c & d & e & f & \\
\hline \multirow[b]{2}{*}{$\begin{array}{l}\text { a. Not respecting } \\
\text { ration }\end{array}$} & a.1 Reducing the specified range from a maximum of $5 \%$ to $2.5 \%$ & 1 & 1 & 3 & 1 & 2 & 2 & 10 \\
\hline & $\begin{array}{l}\text { a. } 2 \text { Adjustment of rations in process to } 2.5 \% \text { and their validation by silicon } \\
\text { breaking strength }>175 \mathrm{~N}\end{array}$ & 2 & 3 & 1 & 3 & 3 & 2 & 14 \\
\hline
\end{tabular}




\begin{tabular}{|c|c|c|c|c|c|c|c|c|}
\hline \multirow{2}{*}{ Cause } & \multirow{2}{*}{ The alternative of improvement } & \multicolumn{6}{|c|}{ Selection criteria } & \multirow{2}{*}{ Total } \\
\hline & & $\mathbf{a}$ & b & c & $\mathbf{d}$ & $\mathbf{e}$ & f & \\
\hline \multirow{2}{*}{$\begin{array}{l}\text { b. Deregulation of } \\
\text { parameters on } \\
\text { machine } 3 \text { head } 6\end{array}$} & $\begin{array}{l}\text { b. } 1 \text { Adjusting the parameters of the machine } 3 \text { the head } 6 \text { according to the } \\
\text { optimal parameters set for the head } 5\end{array}$ & 2 & 2 & 2 & 3 & 2 & 2 & 13 \\
\hline & $\begin{array}{l}\text { b. } 2 \text { Follow the ratios obtained from the headline } 6 \text { alignments with optimal } \\
\text { parameters from head } 5\end{array}$ & 1 & 2 & 1 & 3 & 2 & 2 & 11 \\
\hline $\begin{array}{l}\text { c. Lossless } \\
\text { monitoring }\end{array}$ & $\begin{array}{l}\text { c. } 1 \text { Drafting Loss Sheets and communicating these losses to the logistics } \\
\text { department }\end{array}$ & 1 & 3 & 2 & 1 & 2 & 2 & 11 \\
\hline
\end{tabular}

Adjustment of process ratios to $2.5 \%$ and their validation by silicon breaking strength $>175 \mathrm{~N}$ prioritization of ideas was made on the basis of the large difference between the result obtained by the calculation formula of consumption and ration

Adjusting the machine parameters 3 the head 6 according to the optimal parameters set for the head 5 - on the assumption that it is the same machine and the same type of motors it was considered that optimal parameters obtained for M3 C5 can be applied to C6.

\subsubsection{Designing solutions}

Due to the change in machine parameters, there were little differences between settings 3 and 10 where the track speed was higher for silicone $\mathrm{A}$ and large differences between settings 1 and 12 where track speed was higher for silicon B. For machine 3 head 5 the parameters giving the best result for the 0.22 ration were the ones corresponding to the setting 3 . The next step was to modify the current parameters (setting 2) with the parameters at setting 3 on both the head 5 and the head 6 . From the top data it can see that setting 3 is the optimal one because a lower ration is obtained by modifying parameter D21.

\subsubsection{Validation of solutions}

After changing the machine parameters to setting 3 to validate the $0.22 \%$ rate on both the head 5 and 6 , the ration was made and the silicone resistance to breakage was tested by 2 methods. The ration on the head 5 confirms the initial result, on the head 6 the ratio exceeds the limit of $5 \%$ admitted. Results are confirmed by the silicone tear strength test by: Method 1 - Rapid drying of the parts (in the oven 30 minutes at $80^{\circ} \mathrm{C}$ ) and Method 2 (classic) after 24 hours under normal temperature conditions.

\subsubsection{Measuring the Impact of Improvement}

As a result of the improvement of parameters D21, D31, only a reduction of the ration from $8,33 \%$ to $7,69 \%$ during the period January-May 2015 was obtained on the machine 3 head 5, compared to the target value $(3,5 \%)$ representing improvement of $13.25 \%$.

\subsection{Control}

Based on the results of the DOE parameter analysis, the improvement was achieved with the modification of parameters D21 and D31 only (parameters D21 and D31 have a major influence on ration, D22, D32 have little influence, and D23, D33 insignificant infinity). So extending to all silicone machines can be applied in a simpler way just by doing 4 attempts.

\section{Conclusions}

As a result of the improvement of the parameters only on the machine 3 , the head 5 achieved an improvement of $13.25 \%$ which represents $573 \mathrm{~kg}$ of silicon $\mathrm{B}$, and $1 \mathrm{~kg}$ of silicon costs $12.54 €$. Financial benefits $7185 € / 5$ months

Which means a benefit of $1437 € / 1$ month.

If the action applied to the machine 3 the head 5 would extend with the same results on $\mathrm{M} 1 \mathrm{C} 1$ machines (machine 1 head 1), M1C2 (machine 1 head 2), M2C3 (machine 2 head 2), M2C4 (machine 2 head 4), and M3C6 (machine 3 , head 6) would have a financial benefit of 7185 eur.

Six Sigma is a tool that, if used correctly, can identify the key areas of a business with the advantage that all of the improvements measured and obtained through this technique are directly transformed with financial results. 6 sigma is a philosophy that relies on good resourcesaving and good behavior practices that are geared to the continuous improvement of current work and life so that everything we do and everything we live is more enjoyable, better, more beautiful, cheaper and simpler.

\section{References}

1. Automotive company from Sibiu, Company Technical Documentation, Sibiu (2017)

2. M. V. Zerbes, Advanced planning and design of processes and products in the automotive industry, (Planificarea si proiectarea avansata a proceselor si produselor in industria auto), Editura Techno Media, Sibiu (2017)

3. C.V. Kifor, C. Oprean, Quality Engineering. Improving methodology - 6 Sigma, (Ingineria Calitatii. Imbunatatirea 6 Sigma), Editura Universitatii "Lucian Blaga", Sibiu (2006)

4. M. V. Zerbes, C. V. Kifor, G. Budau, Six sigma methodhology in wood industry organizations, Proceedings of the 7th International Conference on Wood Science and Engineering in the Third Millennium, "Transilvania" University of Brasov, June 4 - 6, (2009)

5. Automotive company, $Q M S$ documentation, Sibiu (2017)

6. I. Masaaki, Gemba Kaizen: A Commonsense Lowcost Approach to Management, (Gemba Kaizen, $O$ abordare practică cu costuri reduse, a managementului,) Editura Finmedia, Bucharest (1997) 